o tym, że to oni tworza biografię bohatera, a nie bohater biografii ma wykreować autora. Zatem problem biografii to problem dzieła i autora. Ten ostatni powinien mieć świadomość, że przedmiot ich opisu zmienia się, co znajduje wyraz tak w pracach naukowych, jak też w literaturze pamiętnikarskiej, której podmiot opisu jest autorem. Oznacza to, że chcąc ukazać różne momenty życia opisywanego bohatera można by pisać nową biografię uwzględniająca określony etap jego dzialalności.

Zatem, autorzy biografii prowadzac badania musza kierować się realizmem poznawczym, liczyć się z wymowa źródel, które wykorzystuja, bowiem ich odczytanie stanowić będzie o wyniku pracy. Rzetelność i krytycyzm powinny towarzyszyć każdemu badaczowi, który posługuje się biografia jako metoda badawcza i formą pisarstwa naukowego, bowiem wydaje się, że biografistyka jest i pozostanie jeszcze długo ważnym gatunkiem twórczości historiograficznej.

Jeśli przyznajemy słuszność istnienia i uprawiania biografistyki, najstarszego z rodzajów pisarstwa historycznego, to warto na zakończenie zastanowić się nad uzasadnieniem tego stanowiska. Ponad osiemdziesiat lat temu, bo w 1922 roku, Wladysław Konopczyński w artykule pt. O polska biografie narodowa napisał: ,Jesteśmy podobno narodem indywidualistów. Dawna Rzeczpospolita stała pono nie rządem, lecz ludźmi. Zdawałoby się, że w takim razie powinniśmy znać swych przodków i społeczników, pamiętać ich, rozumieć, czuć żywo i trwale. Także świętych narodowych - i nie tylko swiętych - obcowanie pogłębia nurt tradycji, wzmacnia wiekuistą tężyznę narodu, nie mówiąc już o tym, że wzbogaca praktyczne doświadczenie obywatela" ${ }^{111}$. Natomiast Tadeusz Lepkowski w ramach dyskusji o problemach biografistyki zorganizowanej przez Redakcję „Kwartalnika Historycznego" wymienia trzy przyczyny, czy też uzasadnienia istnienia biografistyki: pierwsza rozrywka, druga dydaktyka, trzecia nauka ${ }^{112}$. Inaczej celowość badań biograficznych zwłaszcza pedagogicznych uzasadniła Grażyna Karolewicz, która napisała: „Szczególnie ważne są badania biografistyczne, gdy coraz bardziej zacieraja się granice między państwami w dobie jednoczenia się Europy, kiedy zagrożona jest odrębność naszej kultury narodowej, której twórcami byli zawsze ludzie, zwłaszcza wybitni, nieprzeciętni" ${ }^{113}$.

$\mathrm{Z}$ taką argumentacją trudno się do końca zgodzić i twierdzić, że powinniśmy prowadzić badania biograficzne, gdyż zagraża nam jednoczaca się Europa. Boję się, że wówczas przeszlibyśmy od biografii (i w ogóle prac historycznych) pisanych kiedyś ku pokrzepieniu serc, do biografii - obrony. Moim zdaniem badania te, jak i inne nad kultura polską trzeba kontynuować, aby przybliżyć Europie naszą kulturę i jej twórców, gdyż wiedza Europejczyków na nasz temat jest znikoma.

Krzysztof Ratajczak

Poznań

\title{
Miracula z „Żywota świętej Jadwigi”, księżnej Śląska jako źródło do dziejów wychowania
}

Poznawanie przeszłości możliwe jest między innymi dzięki analizie tekstów pisanych - zarówno tych, które zostały wytworzone celowo dla przyszłych pokoleń, jak i tych, które pisane były bez takiego celu. Siłą rzeczy źródła, a zwłaszcza średniowieczne, koncentrowały się na postaciach władców, możnych, hierarchów Kościoła, po macoszemu traktując niższe warstwy społeczeństwa. Niewiele jest

III W. Konopczyński, O polska biografie narodowa, „Przegląd Warszawski"1922 nr 5, s. 161.

112 T. Łepkowski, Biografistyka: zywotność, tradycjonalizm, nowoczesność, "Kwartalnik Historyczny" R. LXXXII 1975, s. $108-109$.

${ }^{113}$ G. Karolewicz, Potrzeba badań nad biografistyka pedagogiczna, Lublin 2002, s. 12. 
(przynajmniej dla polskiego średniowiecza) źródeł pisanych, które pozwalają „wniknąc" do sfery „milczacej większości”, a do wyjątków należą takie, które mówiłyby o mentalności, wychowaniu, opiece nad dzieckiem, poglądach na życie radzinne itp. Stąd też wydaje się celowe poddanie analizie jednego z takich utworów - pochodzacego z pierwszej połowy XIV w. „Żywota świętej Jadwigi”'. Interesować mnie będa wszelkie informacje zawarte $w$ tym tekście, będacym przecież oficjalnym, kościelnym dokumentem, służącym za podstawę procesu kanonizacyjnego Jadwigi, dotyczące szeroko rozumianego wychowania.

Autor Żywota większego, wrocławski franciszkanin, zaznaczył wyraźnie, że czytelnik ma do czynienia $\mathrm{z}$ tekstem, w którym uwzględnił wiele faktów znanych z autopsji oraz przekazu świadków, a nie z legenda czy fantazja ${ }^{2}$. Dalej czytamy: „Zapiski te, przechowywane w klasztorze trzebnickim, odczytałem ponownie jak najdokładniej i porównałem z tymi, które zanotowali inni, znający sprawy z wcześniejszego postępowania. I tak mając materiał pewny, o sprawdzonej wiarygodności [...] włączyłem pewne wydarzenia, które przedstawił w swej kompilacji brat Engelbert z zakonu cysterskiego domu lubiaskiego ${ }^{3}$. Zapewnienia te miały podkreślić wiarygodność tekstu, zwłaszcza w kontekście opisanych cudów, które mialy wydarzyć się dzięki wstawiennictwu Świętej ${ }^{4}$. W 1353 r. na zlecenie Ludwika I Brzeskiego wykonano w Lublinie kodeks zawierający, obok tekstu, serię iluminacji przedstawiających życie świętej Jadwigi ${ }^{5}$. W jednym kodeksie zebrano wówczas żywoty mniejszy i większy św. Jadwigi, dołączono tekst jej genealogii oraz kazanie św. Bernarda o Zwiastowaniu NMP ${ }^{6}$. Żywot większy składa się z dwunastu rozdziałów opisujących dzieciństwo księżnej, jej cechy charakteru, koleje życia oraz katalog cudów, które wydarzyły się dzięki wstawiennictwu Świętej. Żywot podaje sporo informacji biograficznych, z których wywnioskować można o poziomie wykształcenia Jadwigi, jak i o metodach wychowawczych stosowanych na dworze Andechsów.

Jadwiga urodzila się między 1178 a 1180 r., była córka Bertolda IV, hrabiego Diessen-Andechs, przedstawiciela jednego z potężniejszych rodów bawarskich i Anny z rodu Wettynów, córki Degona V, margrabiego Łużyc ${ }^{7}$. Dwór rodziców słynął z wysokiej kultury, sprawowal mecenat artystyczny, był

\footnotetext{
${ }^{\prime}$ Nie zachowaly się bowiem starsze wersje utworu, które niewątpliwie zostaly spisane jeszcze w połowie XIII w., lub bezpośrednio przed procesem kanonizacyjnym. Szerzej na ten temat: T. Wasowicz, Legenda ślaska, Wrocław 1967; por. recenzję A. Karłowskiej-Kamzowej, Studia Źródłoznawcze 16 (1971), s. 213-215. Vita maior spisano w roku 1300, o czym wyraźnie w tekście: Explicit legenda maior et minor de Sancta Hedwigi anno domini millesimo CCC consumata - Vila sanctae Hedwigis, wyd. A. Semkowicz, w: Monumenta Poloniae Historica, t. IV, Lwów 1884, dalej Vita, s. 641. Por. ostatnio: M. Michalski, Kobiety i świętość w zywotach trzynastowiecznych księżnych polskich, Poznań 2004, s. 38 i nn.

${ }^{2}$ Vita, s. 503. Udzial w powstaniu Żywota wziąl także Henryk z Bremy, zob.: K. Jasiński, Franciszek Henryk z Bremy propagatorem kultu sw. Jadwigi, w: Ksiega Jadwizańska. Międzynarodowe Sympozjum Naukowe Swięta Jadwiga w dziejach $i$ kulturze Slaska, Wrocław-Trzebnica $21-23$ września 1993 roku, Wrocław 1995, s. 341. Zauważyé jednak wypadnie, że relacja ustna jest zmienna niemal w nieograniczony sposób por. K. Tymieniecki, Legendy $i$ spór o tradycję historyczna. Studia Źródloznawcze 10 (1965), s. $101 \mathrm{i} \mathrm{nn}$.

${ }^{3}$ Legenda świętej Jadwigi. Z oryginału lacińskiego przetłumaczył A. Jochelson, Wrocław 1993, s. 28. Wszystkie cytaty polskie pochodza z tego wydania. Dla wygody Czytelnika podczas analizy treści mirakulów będę posługiwać się wylacznie polskim tłumaczeniem, w innych wypadkach podaję odsylacze do edycji lacińskiej w $M P H$. Żywot autorstwa Engleberta powstal ok. 1262 r., prawdopodobnie z inicjatywy księcia Henryka V Brzuchatego (ok. 1248/52 - 1296) i jego żony Ełżbiety (1263 - 1304). Tekst zaginal po 1810 . Por.: M. Michalski Kobiety i świętośc, s. 46.

${ }^{4}$ Por.: J. Pater, Wartości historyczne ,Żywota większego świętej Jadwigi", w: Ksiega Jadwizańska, s. 178 - 187. O wiarygodności historycznej żywotów świętych zob.: S. Kwiatkowski, Miracula średniowieczne jako źródlo do badań nad mentalnościa spoteczna w Polsce $i$ jej przemianami pod wpływem kolonizacji niemieckiej, Studia Źródłoznawcze 12 (1977), s. 97 i nn.; B. Kürbis, Zywot blogostawionej Salomei jako źródlo historyczne, w: tejże, Na progach historii. Prace wybrane, Poznań 1994, s. 9 - 16; P.M. Ksyk, Vita Annae ducissae Silesiae, Nasza Przeszłość 78 (1992), s. 127 i nn.

${ }^{5}$ Stan badań nad źródłami do życia świętej Jadwigi zestawiła $\Upsilon$. Wasowicz, Legenda ślaska; ostatnio A. Skiba, Święta Jadwiga, księzna ślaska w źródtach i opracowaniach historycznych, Przegląd Zachodniopomorski 46 (2002), z. 3, s. 129-139; M. Michalski, Kobiety i świętość, s. 61-68. Zob. również: M.L. Wójcik, Materiały rękopiśmienne dotyczace św. Jadwigi w zbiorach Biblioteki Uniwersyteckiej we Wroctawiu, w: Ksiega Jadwizańska, s. 234 - 249. s. 214 .

${ }^{6}$ G. Labuda, Twórczość hagiograficzna i historiograficzna Wincentego z Kielc, Studia Źródłoznawcze 16 (1971),

7 B. Suchoniówna, Jadwiga (ok. 1178]80-1243), w: Polski Slownik Biograficzny, dalej PSB, t. X, Wroctaw 1962 - 1964, s. 297-299; taż, Święta Jadwiga, księżna ślaska, Nasza Przeszłość 53 (1980), s. 5-132. Por.: J. Gottschalk, S. Hedwig. Herzogin von Schlesien, Köln-Graz 1964; tenże, Hedwig von Andechs - Herzogin von
} 
skupiskiem twórców poezji rycerskiej, malarzy i rzeźbiarzy. Pamiętać musimy, że księżna Śląska pochodziła $z$ jednej z najświetniejszych rodzin Cesarstwa, wychowywała się w środowisku o wysokiej kulturze i smaku artystycznym. Była przyzwyczajona do samodzielnej lektury, czym zapewne imponowała mężowi ${ }^{8}$. Jadwiga odebrała staranne wychowanie $w$ klasztorze benedyktynek w Kitzingen, znajdujacym się na terenie diecezji Würzburg. Z tekstu Żywota dowiadujemy się, że Jadwiga od dzieciństwa posiadała nieprzeciętna dojrzałość (cor senile), lubiła pracować, unikała natomiast łatwizny. We wszystkich sprawach nauczycielami jej byli wyznaczeni przez rodziców opiekunowie. Jest to cenna wskazówka, ponieważ sama Jadwiga poczuwała się później do swych rodzicielskich obowiązków. Księżniczka ,nigdy nie uczestniczyła w zabawach, unikała kontaktów z tymi, którzy gonili się w igraszkach” (ne participem prebebat). Dzięki tej uwadze możemy wniknąc w niedostępny pozornie świat średniowiecznych zabaw - zapewne gonitwy były ulubioną forma zabawy na feudalnych dworach, a sądzić należy, że i w uboższych domach. Wiemy również, że w Kitzingen uczyła się Pisma Świętego, a w wieku 12 lat została poślubiona księciu śląskiemu ${ }^{9}$. Nie ulega wątpliwości, że znała łacinę w mowie i piśmie: „w chwili śmierci Jadwiga rozmawiała w języku literackim [tj. po łacinie]" 10 . Źródło podaje również informacje dotyczące rodzeństwa Jadwigi - miała czterech braci (Otton VII, Henryk IV, Bertold, Ekbert) i trzy siostry (Agnieszka, Gertruda, Mechtylda), z których jedna (Mechtylda, zm. 1254) została mniszka w Kitzingen ${ }^{11}$.

Do Polski przybyła ok. 1190-1192 r., jako przyszła żona Henryka Brodatego, syna Bolesława Wysokiego i Krystyny, urodzonego w Legnicy w 1168 r. ${ }^{12}$ Do ślubu z księciem ślaskim doszło między 1186 a 1190 , nie wiadomo czy w Andechs, czy już na Śląsku ${ }^{13}$. Małżeństwo ksiażęcej pary było zapewne szczęśliwe, choć $w$ tekście Żywota odnajdujemy ciekawą wzmiankę dotycząca alkowianych stosunków: mianowicie księżna zaraz po poczęciu rezygnowała całkowicie z kontaktów cielesnych $\mathrm{z}$ mężem aż do chwili urodzenia dziecka. Tę zasadę konsekwentnie stosowała przy każdej ciąży. Fakt ten interpretować można jako przejaw religijności księżnej, ale też jako odbicie w tekście obyczaju, czy przesądu dotyczacego prawidłowego przebiegu ciąży. Religijność przyszłej świętej nie pozostawia żadnych wątpliwości: księżna oddawała się częstym medytacjom, podczas których ,czytała modlitwy z leżącej przed nią książki" " ${ }^{4}$, w innym miejscu tekstu spotykamy wzmiankę: ,inne miejsca Pisma czytywała swymi oczami i wypełniała uczynkami Jadwiga, aktywnie uczestniczyła w chrystianizacji wewnętrznej Śląska, a jednym z przejawów tej aktywności stała się trzebnicka fundacja, na którą przeznaczyła 50 tysięcy grzywien srebra ${ }^{13}$. W 1202 r. ufundowała w Trzebnicy żeński klasztor cysterek $^{16}$, sprowadzonych w styczniu 1203 r., za pośrednictwem brati Jactwigi biskupa bamberskiego Ekberta, z klasztoru pod wezwaniem Najświętszej Marii Panny i św. Teoulura w Bambergu ${ }^{17}$. Na czele

Schlesien. Eine Botin des Friedens, Freiburg-Basel-Wien 1982; A. Kiełbasa SDS, Święta Jadwiga slaska, w: Polscy święci, t. 9, Warszawa 1986, s. 22-66.

${ }^{8}$ Vita: o wykształceniu s. 512, o tekturze w lóżku s. 557, lekturze podczas posilk6w s. 536.

${ }^{9}$ Hedwigis, habens etatis annos duodecim [...) matrimonialiter iugebatut, Vita, s. 514.

${ }^{10}$ Legenda swiętej Jadwigi, s. 66.

11 Por.: J. Swastek, Rodzina święej Jadwigi, w: Ksiega Jadwizańska, s. 44-59.

12 K. Jasiński, Rodowód Piastów ślaskich, t. 1: Piastowie wroctawscy i legnicko-brzescy, Wrocław 1973, s. 74 i nn.

13 B. Zientara, Henryk Brodaty $i$ jego czasy, wyd. 2, Warszawa 1997, s. 44.

${ }^{14}$ Legenda świętej Jadwigi, s. 56.

15 Koszt budowy klasztoru wyniós 20 tysięcy grzywien, natomiast olowiane blachy do pokrycia dachów oznaczały wydatek kolejnych 30 tysięcy grzywien. Legenda świętej Jadwigi, s. 58.

${ }^{16}$ Fundacja zostala dokonana przed 22 listopada 1202 r., skoro tego dnia papież Innocenty III objał opieka Stolicy Apostolskiej posiadłości klasztoru - Codex diplomaticus nec non epistolaris Silesiae, ed. K. Maleczyński, t. I, Wroclaw 1956, nr 92, s. 227 -228. Por. dokument Innocentego III z 4 listopada 1205 r;; ibidem, t. II, Wroclaw 1959, nr 120, s. 3-4 oraz dokument tegoż z 8 stycznia 1207, ibidem, nr 127, s. $18-19$.

${ }_{17}$ M. Siuchniński, Pochodzenie i pierwotna przynależność zakonna konwentu cystersek $w$ Trzebnicy, Roczniki Historyczne 12 (1936), s. 187 i nn.; K. Bobowski, Fundacja i poczatki klasztoru cystersek w Trzebnicy, Acta Universitatis Wratislaviensis 1471, Historia 106 (1993), s. 31 i nn.; M. Daniluk, Cysterki, w: Encyklopedia Katolicka, t. III, Lublin 1985, k. 718 i nn.; A. Kiełbasa, Zatożenie pierwszego klasztoru zeńskiego na Ślasku jako program wychowania $i$ kształcenia kobiet, w: Materiaty z konferencji „Kościót na Ślasku w okresie średniowiecza”, red. K. Matwijowski, Sobótka 53 (1998), nr 3-4, s. 457 i nn. 
konwentu stanęła ksieni Petrissa, dawna wychowawczyni księżnej ${ }^{18}$. Dzięki protekcji fundatorki Trzebnica została w 1218 r., jako pierwszy klasztor żeński, przyjęta do kongregacji cysterskiej. Po dwudziestu latach małżeństwa i urodzeniu siedmiorga dzieci Jadwiga zamieszkała wraz z kilkoma dworkami w klasztorze trzebnickim. Po śmierci męża w 1238 r. nie zdecydowała się na złożenie ślubów zakonnych. Zmarła w klasztorze 14 października 1243 r., a kanonizowana została 26 lutego 1267 r.

Dwór księżnej był swego rodzaju szkoła dla panien $\mathrm{z}$ arystokracji, a zwłaszcza dla przedstawicielek dynastii ${ }^{19}$. Spotykamy tu córkę króla Czech Przemysła Ottokara - Annę, po ukończeniu lat sprawnych, żonę syna Jadwigi, Henryka Pobożnego ${ }^{20}$ oraz jej siostrę Agnieszkę, która w latach 1214-1217 wychowywała się $w$ Trzebnicy, a po śmierci narzeczonego (nieznanego $z$ imienia syna Henryka Brodatego i Jadwigi) powrócila do Czech ${ }^{21}$, Zbysławę-Adelajdę - najmłodsza siostrę Henryka Brodatego oraz jej pięciu synów ${ }^{22}$. Jadwiga została po raz pierwszy matka w wieku 14 lat ${ }^{23}$, a w ciagu dwudziestu lat małżeństwa przyszło na świat siedmioro dzieci: Bolesław, Agnieszka, Zofia, Konrad Kędzierzawy, Henryk Pobożny i Gertruda oraz nieznanego imienia $\operatorname{syn}^{24}$, z których troje umarło w młodym wieku, zapewne jeszcze przed 1214 r. (Zofia, Agnieszka i Bolesław i NN) ${ }^{25}$. Żywot nie podaje zbyt wielu szczegółów o Jadwidze jako matce, jedynie bulla kanonizacyjna podaje, że "wychowywała swe dzieci w bojaźni Bożej"26.

W klasztorze trzebnickim wychowywało się szereg księżniczek piastowskich ${ }^{27}$, część z nich odbierało tu tylko edukację, a klasztor traktowany był jako swego rodzaju „,przechowalnia”, z której bez ogródek zabierano te księżniczki, które należało wydać za maż w momencie, gdy potrzebowała tego polityka dynastyczna. Doskonałym tego przykładem są opisane w Żywocie losy sióstr, córek Henryka

${ }^{18}$ B. Zientara, Petrissa, w: PSB, t. XXV, Wroctaw 1980, s. 689.

19 Jadwiga utrzymywała na dworze wiele panien szlacheckiego, a nawet i plebejskiego pochodzenia, osieroconych przez rodziców. Uczyla je śpiewu, haftu, a następnie wydawała za mąż lub posyłała do klasztoru. Zob. A. Kiełbasa SDS, Swięta Jadwiga Ślaska jako wychowawczyni wtasnych dzieci i swoich wnuków, Trzebnica 1996; K. Dola, Postawa religijna świętej Jadwigi. Próba charakterystyki, w: Ksiega Jadwizańska, s. 113; A. Daroszewska, Otoczenie Henryka Brodatego i Jadwigi jako środowisko spoleczne, Warszawa 1978, passim; M. Chołodowska, Matka - opiekunka matoletnich dzieci w Polsce wczesnośredniowiecznej na podstawie opisów cudów sw. Jadwigi $i$ śs. Stanistawa, w: Partnerka, matka, opiekunka, status kobiety w starożytności i średniowieczu, red. J. Jundzill, Bydgoszcz 1999 , s. 260 i nn.

${ }^{20}$ R. Grodecki, Anna, w: PSB, t. I, Kraków 1935, s. 117-119. Benedykt Zientara błędnie przypisuje narzeczeństwo Agnieszki, Annie, twierdzac, że poczatkowo Anna zaręczona była z innym synem Jadwigi i Henryka Brodatego Konradem. B. Zientara, Henryk Brodaty $i$ jego czasy, s. 169.

${ }^{21}$ K. Jasiński, Dziatalność czeskich Dypoldowiców na Ślasku w pienwszej połowie XIII w., w: Społeczeństwo Polski średniowiecznej. Zbiór studiów, red. S.K. Kuczyński, t. IV, Warszawa 1990, s. 185; tenże, Rękopis zwany nekrologiem czesko-ślaskim, w: Polska - Slask - Czechy. Studia nad dziejami stosunków kulturalnych i politycznych w średniowieczu, red. R. Gładkiewicz, Acta Universitatis Wratislaviensis, Historia LXXXI, Wrocław 1994, s. 42. B. Zientara, (Henryk Brodaty i jego czasy) podaje niekonsekwentnie, że narzeczonym Anny, (s. 169), a nieco dalej Agnieszki (s. 253) był Konrad. Uczony podaje też błędna chronologię pobytu królewny czeskiej w Trzebnicy, umieszczajac ją w latach $1207-1213$, ibidem, s. 253. Por. K. Jasiński, Uwagi o genealogii Piastów ślaskich w XIII w. Studia Źródłoznawcze 10 (1965), s. 144. s. 254 .

${ }_{22}$ A. Kiełbasa SDS, Święta Jadwiga Ślaska jako wychowawczyni, s. 38; B. Zientara, Henryk Brodaty i jego czasy,

${ }^{23}$ Vita, s. 514 .

${ }^{24}$ K. Jasiński, Rodowód, t. 1, s. 94 i nn.; Z. Kozlowska-Budkowa, Gertruda (zm. po 1268), w: PSB, t. VII, Kraków 1948 - 1958, s. 407-408. Bolesław ur. 1194, Konrad Kędzierzawy ur. ok. 1198, Henryk II Pobożny ur. przed 1207 r., Agnieszka ur. w latach dziewięćdziesiątych XII w., Zofia, Gertruda ur. 1200 r., NN syn ur. 1208. W dniu 25 XII 1208 r. trzymał go do chrztu Władysław Laskonogi.

is Bolesław zmari ok. 1206-1208, Konrad zmarł w następstwie nieszczęsliwego wypadku na polowaniu w okolicach Trzebnicy w 1213 r., Agnieszka zm. 11 V przed 1214 r., NN zmarł ok. 1214-1217. K. Jasiński, Rodowód, t. 1, s. 95, 101, 105; por.: B. Suchón OSB, Księżna Jadwiga, s. 38.

${ }^{26}$ Bulla quam Clemens papa quartus ad laudem sanctae Hedwigis composuit, w: Der Hedwigs-Codex von 1353, Sammlung Ladwik, wyd. W. Braunfels, t. 2, Berlin 1972, s. 167-175 oraz w: Scriptores Rerum Silesiacarum, wyd. G.A. Stenzel, t. II, Breslau 1839, s. $119-126$

${ }_{27}$ Vita, s. 517. Listę Piastównien w klasztorze trzebnickim podaje P. Wiszewski, Zwiazki fundatorów z klasztorami Zeńskimi na Slasku (XIll-potowa XIV w.). Wybrane aspekty, w: Genealogia. Wladza i spoteczenistwo w Polsce średniowiecznej, red. A. Radzimiński, J. Wroniszewski, Toruń 1999, s. 324 i nn. (zwłaszcza zestawienie tabelaryczne). 
Pobożnego i Anny: Agnieszki ${ }^{28}$ i Elżbiety ${ }^{29}$, która zostala w 1244 r. zabrana z klasztoru przez brata - Bolesława Rogatkę w celu wydania za mąz ${ }^{30}$. Prawdopodobnie w klasztorze wychowywała się u boku babci również trzecia siostra: Jadwiga, o której „Kronika polska” informowała, że była niedorozwinjęta umysłowo (prawdopodobnie jednak fizycznie, jak sądził Kazimierz Jasiński) ${ }^{31}$. W późniejszym okresie Trzebnica była rodowym klasztorem Piastów, a godność opacka znajdowała się w rękach przedstawicielek dynastii aż do $1466 \mathrm{r}^{32}$

Jadwiga czytała żywoty świętych i w późniejszym okresie świadomie pragnęła zostać święta. W tym celu umartwiała się, ćwiczyła pokore, co było zapewne niezwykle trudne dla silnej i władczej osobowości księżnej, czyniła ponadto niezliczone dobre uczynki wypraszając u męża łaskę dla skazanych, opiekując się ubogimi. Na osobowość księżnej musiały wpłynąć klasztorne wychowanie i zapewne głęboka religijność, ale również i splendory dworskiej kultury - tumieje rycerskie, występy minnesängerów. Świadectwem tego świeckiego aspektu wychowania księżnej jest niewatpliwie jej wyobrażenie na pieczęci, zgodne z ówczesna modą. Pieczéć ukazuje ja w modnej wówczas na zachodzie Europy obcisłej sukni z rozwiniętymi, bardzo wydłużonymi rękawami. Podobne przedstawiona jest Jadwiga na tympanonie kościoła w Trzebnicy. Widać zatem, że Jadwiga nie unikała przepychu w strojach ${ }^{33}$.

Na dworze księżnej, wyraźnie oddzielonym od ksiazzęcej auli, przestrzegano surowych postów, dwór brał udział w licznych nabożeństwach, a księżna sprawdzała znajomość zasad wiary i podstawowych modlitw ${ }^{34}$. Żywot stwierdza również, że księżna wraz z dworkami przygotowywala paramenta i szaty liturgiczne ze złota i jedwabiu. Religijność księżnej wymagała obecności odpowiednich lektur: zbiorów modlitw, psałterzy, żywotów świętych itp. ${ }^{35}$ Można we fragmentach odtworzyć ten księgozbiór: zachowały się bowiem Godzinki czyli oficjum o Najświętszej Marii Pannie z licznymi ilustracjami ze Starego i Nowego Testamentu wraz z kalendarzem, zawierającym nekrolog Andechsów, Przemyślidów oraz daty zgonu mniszek trzebnickich, wpisywane prawdopodobnie ręka Jadwigi ${ }^{36}$. W jej posiadaniu znajdowały się także tzw. Psalterz nocny, pochodzący z Lubiąża oraz Legenda św. Bernarda ${ }^{37}$.

Dwór księżnej skupiał szereg osób obojga płci: obok urzędników dworskich (np. notariusz Ludolf, kanclerz magister Marcin), duchownych (spowiednik i kapelan Gunter, Mateusz, Lutpold, Ambroży) i rycerzy spotykamy w nim liczny orszak dworek i dworzan; pokojowcami Jadwigi byli synowie możnych śląskich. Z dokumentów znani są ponadto podkomorzy (subkameralius), lekarz, zarzadca kuchni dla ubogich, których stale utrzymywano w liczbie trzynastu (na wzór Chrystusa i apostołów) ${ }^{38}$.

${ }^{28}$ Z. Kozłowska-Budkowa, Agnieszka, w: PSB, t. I, s. 31. Agnieszka najpóźniej w 1248 r. została zakonnica trzebnicka, a w latach 1269-1278 pełniła godność opatki, wtedy zrezygnowala z urzędu, zachowując zarzą nad dobrami klasztoru. K. Jasiński, Rodowód, t. 1, s. $125-127$.

${ }_{29}$ Z. Kozłowska-Budkowa, Elźbieta (zm. 1265), w: PSB, t. VI, Kraków 1948, s. 259; K. Jasiński, Rodowód, t. 1, s. 117 podkreśla, że Elżbieta nie musiała w tym momencie być zakonnica, a jedynie wychowywać się w klasztorze.

${ }^{30}$ [1244] item anno prescripto dux Przemyslius Polonie uxorem duxit filiam condam Henrici duxis Slezie - Rocznik kapituly gnieźnieńskiej, w: MPH s.n., t. VI, Warszawa 1962, s. 7. Elżbieta urodziła bliźnięta, co było bardzo rzadkim zjawiskiem w średniowieczu - [1253] domina Elisabeth uxor ducis Premislonis simul geminas filias peperit, Rocznik kapituly poznańskiej, w: MPH s.n., t. VI, s. 33.

${ }^{31} M P H$, t. III, s. 651 : due in Trebnicz degebant, quarum [...] altera infirma corpore tunc, sed postmodum robusta, mente vero infirma et animo pertinacissima in claustro relicta, que tandem per matrem ordini Minorum fratrum tradito fuit ad Sanctam Claram Wratizlavie. Jadwiga urodzona ok. 1238 - 1241 była jedna z najdłużej żyjacych Piastówien - zmarła 3 kwietnia 1318 r. - por.: K. Jasiński, Rodowód, t. 1, s. 133 - 134.

${ }^{32}$ B. Suchoń, Swięta Jadwiga, s. 62.

${ }^{33}$ B. Zientara, Henryk Brodaty i jego czasy, s. 345.

34 Vita, s. 543.

${ }^{3 s}$ Zob.: H. Szwejkowska, Biblioteka klasztoru cystersek w Trzebnicy, Wroclaw 1955.

36 Historia Ślaska, t. 3: Sztuka, Kraków 1936, s. 199-210; K. Jasiński, Wielkopolskie reminiscencje w tzw. Godzinkach sw. Jadwigi, Zapiski Historyczne 52 (1987), s. 36 i nn.; M. Pawłowski, Czeskie noty obituralne w Nekrologu trzebnickim, Studia Źródloznawcze 25 (1980), s. $97-108$.

${ }^{37}$ K. Jażdżewski, Biblia henrykowska IF13 i Psalterz trzebnicki IF440. Dzieta kaligraficzne cystersa lubiaskiego z lat 1238-1245, Studia Źródłoznawcze 25 (1980), s. 117 i nn.; J. Długosz, Modlitewnik trzebnicki „Cursus Sanctae Mariae" z pienwszej polowy XIII wieku, w: Ksiega Jadwizańska, s. 118-124.

${ }^{38}$ B. Suchoń, Święta Jadwiga, s. 53. 
Wśród dworek Jadwigi były zarówno młode dziewczęta, jak i dorastające panny oraz wdowy (ancillae, famulae, pedisequae oraz niewiasty stużebne - mulier serva). Niektóre dworki cieszyły się szczególnymi względami. O Katarzynie, pochodzącej z Prus autor Żywota zapisał: femina, quia specialiter extitit familians. Część dworek stanowiły ubogie panny, sieroty. Najważniejsza postacia kobiecą dworu była z cała pewnością Demundis, powiernica tajemnic księżnej (secretaria) oraz prokuratorka (prokuratoria). Znaczna pozycję posiadały również Adelajda, wdowa po Volkmerze z Legnicy. Zofia, Adelajda, wdowa po Teodoryku z Janowic i niejaka Milezja. Do grupy dworek Jadwigi, które księżna wychowywała od dziecka a następnie zapewniła klasztorna edukację zaliczyć można m.in. Racławę, która jako mniszka trzebnicka wysłana została do klasztoru cysterek w Owińskach, gdzie sprawowała później godność ksieni ${ }^{39}$ oraz Wiktorię, Adelajdę, Wieńczysławę - późniejsza przeoryszę trzebnicka, Pinozę, Juliannę, Juttę, Benedyktę. Z osobą świętej związana była ponadto pisarka trzebnicka Gosława, która zanotowała modlitwe podyktowana choremu przez Jadwigę 40 $^{40}$ Dworki księżnej były osobami wykształconymi, o jednej tylko Benedykcie Żywot zaznacza, że była analfabetką (litteris imbuta) ${ }^{41}$.

Warto wspomnieć, że treść „Żywota świętej Jadwigi” dostępna była ówczesnym odbiorcom również w formie ,komiksowej”. „Legenda obrazowa” z 1353 r., sporządzona dla księcia Ludwika I Brzeskiego i jego żony Agnieszki ${ }^{42}$ przez Mikołaja Pruzię, jest cennym źródłem ikonograficznym ${ }^{43}$. Legenda obrazowa została dostosowana do zilustrowania wszystkich przekazów o św. Jadwidze. Legenda znalazła się po śmierci fundatora w rękach kanoników brzeskich. W czasie reformacji kodeks znalazł się w posiadaniu księżnej Marii Benigny z rodu Piastów, żony Oktawiusza Piccolomini i ofiarowany został przez nią klasztorowi pijarów w Ostrawie na Morawach ${ }^{44}$.

Wydaje się, że najciekawsza poznawczo częścią Żywota sa dołaczone doń opisy cudów, zdziałanych za pośrednictwem Jadwigi. Miracula powstawały bowiem z zeznań świadków, samych pąników. W ich obecności były niejednokrotnie odczytywane lub opowiadane. Informacje dotyczące cudów były sprawdzane przez inkwizytorów ${ }^{45}$, a i sam autor wyraźnie zaznaczał sytuacje, w których nie mógł powołać się na zeznania naocznych świadków ${ }^{46}$. Są one znakomitym źródłem do badania mentalności i dziejów społeczno-obyczajowych ${ }^{47}$. Przykladem może być opowiadanie o pewnej dziewczynie, która ,utraciła dziewiczą niewinność, wstydząc się ludzi udawała w sercu i ubiorze, że ja posiada" ${ }^{48}$. Wiemy, że wśród szlachty, a zwłaszcza w kręgu dynastycznym, zwracano ogromną uwagę na ten aspekt - przypomnieć należy, że często badano dziewczęta przed nocą poślubną. Zwraca również

${ }^{39}$ Vita, s. 552, 572, 577. Na temat klasztoru w Owińskach zob. ostatnio: K. Ratajczak, Szkic z dziejów opactwa cysterek w Owinskach. 750. rocznica fundacji, Nasza Przeszłość 98 (2002), s. 531 -548; tenże, Proces fundacyiny klasztoru cysterek w Owinskach i zarys jego średniowiecznych dziejów, w: Cysterki w dziejach i kulturze ziem polskich, dawnej Rzeczypospolitej i Europy Środkowej. Materiaty z siódmej Międzynarodowej Konferencji Cystersologów odbytej z okazji 800. rocznicy fundacji opactwa cysterek w Trzebnicy, Trzebnica 18-21 września 2002 r., red. A.M Wyrwa, ks. A. Kiełbasa SDS, ks. J. Swastek, Poznań 2004, s. 634-647. Tu dalsza literatura

40 Vita, s. 589.

41 Vita, s. $576,579$.

42 Ludwik I byl synem Bolesława ks. brzeskiego, ur. ok. 1313, zm. XII 1398; Agnieszka byla córka Henryka Wiernego, ks. glogowsko-żagańskiego ur. 1312, zm. 1362. K. Jasiński, Rodowód, t. 1, s. 179.

M. Rehorowski, Sprzęty przedstawione w miniaturach Kodeksu z Brzegu (z roku 1353), Sobótka 12 (1957), z 2, s. 137 i nn.; A. Karlowska-Kamzowa, Zagadnienie aktualizacji w silaskich wyobrazeniach bitwy legnickiej 1353-1504, Studia Źródłoznawcze 17 (1972), s. 91 -118; por. również inne prace Autorki na ten temat.

${ }^{44}$ B. Suchó, Święta Jadwiga, s. 115. "Legenda obrazowa" jako źródło do historii wychowania stanie się przedmiotem osobnego opracowania.

45 "Ojciec tego chłopca w czasie badania inkwizytorów zeznał o cudzie, chociaż ledwie mógł mówić z powodu lez i szlochu wdzięczności”, Legenda świętej Jadwigi, s. 84; „Chłopiec ów [...] w czasie badania cudów przedstawiony został inkwizytorom jako zdrowy dla potwierdzenia prawdziwości cudu”, s. 85; „dziewczynka [...] odzyskała wzrok i widziala już wszystko. Stwierdzili to inkwizytorzy, którzy ja widzieli", s. 91.

46 "Chociaz siostra $w$ chwili cudu była przy grobie św. Jadwigi sama i nikt nie mógl dać świadectwa [...] jednakże cały konwent [...] przez dlugi czas był Swiadkiem jej gluchoty". Tamże, s. 92.

${ }^{47}$ Por. A. Witkowska, Miracula średniowieczne. Forma przekazu i mozliwości badawcze, Studia Źródłoznawcze 22 (1977), s. 83-87; S. Kwiatkowski, Miracula średniowieczne jako źródla do badań nad mentalnościa spoteczna w Polsce $i$ jej przemianami pod wptywem kolonizacji niemieckiej, tamże, s. 97-103.

${ }^{48}$ Legenda swiętej Jadwigi, s. 87. 
uwagę wiadomość o różnicach w stroju kobiet zamężnych, panien oraz dziewic. Obyczaje małżeńskie obserwujemy w opowieści o Zdzisławie, żonie Przybysława z Trzebnicy, która mąż chciał porzucić z powodu utraty wzroku i związać się z konkubina, „bo prawnie pojać jej za żonę nie mógł”. Mentalność przedstawicieli niższych stanów społecznych śledzić możemy na podstawie historii pewnego robotnika, który przybywszy z trzyletnim synem do Wrocławia, zgubił go w trakcie jarmarku. Zrozpaczony ojciec ofiarował świętej Jadwidze „miarę pszenicy tej wagi, jaką [...] chłopiec uzyska na jej szali" 50. Ojciec ofiarował zatem coś bardzo cennego dla niego w zamian za odzyskanie syna. Informacje zawarte $w$ tej części Żywota sa również niezwykle cenne $z$ punktu widzenia historii wychowania. Odnajdujemy w opisach cudów wiadomości dotyczące sfery uczuć rodziców do dzieci. Przeważa wśród nich uczucie miłości do dziecka, co przeczy mocno zakorzenionej w literaturze tezie o braku wykazywania takowych uczuć przez ludzi średniowiecza. Najczęściej rozpacz po śmierci dziecka jest udziałem kobiet, choć odnajdujemy również świadectwa podobnych reakcji ojców: gdy szlachcic Witosław z Borku usłyszał o chorobie syna „zapłakal"51. Matki były najczęściej stroną aktywną w działaniach zmierzających do przywrócenia zdrowia dzieci - to one wzywały lekarzy (,Matka jego zatem poleciła chirurgowi zastosować nacięcie, które jednakże nie dało rezultatu" ${ }^{52}$ ). Co ciekawe, działo się to również w przypadku zamężnych już dzieci ${ }^{33}$.

Odnajdujemy w tekście informacje o wychowawcach dzieci. Zauważyć można, że patrycjat miejski zatrudniał niańki: „Chłopiec Walter, syn bogatego mieszczanina wrocławskiego Emila, wskutek upadku niosącej go niańki [...] mocno się potłukt" ${ }^{\prime 4}$. Mieszczanie posiadali również do pomocy służbę domową; wiemy choćby o Bogdance, służącej Adelajdy, wdowy po Folkmarze z Legnicy ${ }^{55}$, czy o służących Mateusza z Tyńca ${ }^{56}$. Wychowawców zatrudniali również przedstawiciele bogatych rodów rycerskich - takowa informacje posiadamy w przypadku Wincentego, kasztelana z Olesna ${ }^{57}$. Czasami o opiekę nad dzieckiem zwracano się ad hoc, planując podróż, zbyt uciażliwą dla malych dzieci: Elżunia, matka 7-tygodniowej Pietruchy, „chcac udać się do pewnego miasta, poprosiła niewiastę imieniem Boguslawa, aby zaopiekowała się niemowlęciem, dopóki nie powróci po załatwieniu swoich spraw" 58 .

Pewne wskazówki dotyczące wychowania dworskiego odnajdujemy w opowiadaniu dotyczacym uzdrowienia Piotra „dworzanina i przyjaciela księcia Henryka" ${ }^{99}$. Jeżeli przyjąć, że mowa tu o Henryku Pobożnym, a nie o jego ojcu, można pokusić się o hipotezę, w myśl której książęta wychowywani byli w grupie chłopców - synów rycerstwa śląskiego, którzy następnie zostawali doradcami władców. Być może wychowania rycerskiego dotyczy wzmianka o ośmioletnim chłopcu Dominiku, synu rycerza Witosława z Borku, kopniętym „przez konia w skroń tak potężnie, że uważano chłopca za zmarłego" 60 podczas nauki jazdy konnej - nieodzownego składnika rycerskiej edukacji?

49 Tamże, s. 91. Jest to skądinąd świadectwo upowszechnienia się na Śląsku w dnugiej połowie XIII w. nakazanego przez sobór laterański IV (1215) obowiazku zawierania ślubu ad facie ecclesie.

50 Tamże, s. 87.

${ }^{51}$ Tamże, s. 84. Rodzice Dobromiły: rycerz Klemens z Jeszkotli i jego żona boso pielgrzymowali do grobu świętej „i ze tzami błagali Boga" o zdrowie dla niej, tamże, s. 106. Kontrastuje tu postawa Kuna, z pochodzenia Francuza, a obywatela wrocławskiego, który wolal wycofać się z modłów o zdrowie córki, gdy napotkał przy grobie świętej wielką liczbę kobiet, ,matka zaś pozostała przy córce” i modliła się żarliwie, s. 97. Charakterystyczna wydaje się postawa Sulisławy, babci małej Witosławy, która „opłakiwała nie tyle martwe niemowlę, ile raczej fakt, że zmarlo bez sakramentu chrztu"; tamże, s. 113.

52 Tamże. Podobnie Mechtylda, mieszczka wrocławska, matka Elżbiety, s. 85.

53 Np. matka Maguszy, żony Andrzeja z Michałowic „złożyła ślub, że odwiedzi z córka grobowiec świętej”, jeżeli ta przywróci jej „mowę i władzę w nogach". Tamże, s. 92.

54 Tamże, s. 84.

ss Tamże, s. 95.

56 Tamże, s. 104

57 Syn kasztelana, dwuletni Wilhelm pozostawiony zostal przez swego opiekuna bez nadzoru nad brzegiem Odry, a sam poszedł się kapać. Dziecko wpadło do wody i utonęło. Tamże, s. 112.

58 Tamże, s. 113.

99 Tamże, s. 85.

60 Tamże, s. 110. 
Stosunkowo niewiele posiadamy w Miraculach informacji wprost mówiących o poziomie wykształcenia przybywajacych do grobu Jadwigi. Niejaki Michał, brat Gaudencji, mniszki trzebnickiej określony został jako „człowiek niezbyt uczony”. W trakcie modłów zostal nauczony przez „męża w białych szatach" modlitwy (zapewne w języku łacińskim), którą następnie opowiedział zakonnicom. „Jedna z sióstr, Gosława, zapisała modlitwę usłyszaną z ust owego męża, któremu się to zdarzyło, i pozostawila na piśmie potomnym dla uczczenia cudu"61. Mniszki były zatem kształcone, zapewne w szkole klasztornej działajacej w Trzebnicy. Wśród społeczności Śląska w połowie XIII w. wykształcenie było istotna wartościa, skoro niejaka Beatryks, matka małego Henryka, ,przygnębiona stanem syna”, modliła się do św. Jadwigi: ,jeżeli go wyleczysz, to ślubuję i obiecuję ci, że dam mu wykszıłałcenie i oddam ci go na dożywotnia służbę" ${ }^{2}$ - co oznaczało przeznaczenie syna do stanu duchownego. Wykształcenie mogli bowiem zdobyć praktycznie tylko duchowni; w tekście analizowanej części Żywota spotykamy bodaj jednego wykształconego świeckiego - niejakiego magistra Hermana, chirurga wrocławskiego ${ }^{63}$. Wiemy, że jakieś wykształcenie zdobyl ,pochodzacy z Bierutowa chłopak Jan”, który po uleczeniu z choroby ,został wysłany do szkół i nauczył się łaciny, a matka jego wypełniając ślubowanie pozostala we wdowieństwie". Matka chłopca Helwiga ślubowala bowiem, że "Zawsze pozostanie we wdowieństwie, byleby Jadwiga uzdrowiła syna" ${ }^{64}$. Wśród duchownych wykształcenie bylo wówczas dość powszechne, również wśród zakonnic - „Agnieszka, Krystyna, Małgorzata, Joanna, siostry z klasztoru trzebnickiego, odbywały pobożne czuwanie czytając psalterz" 65 .

W opowieściach o różnych cudach, zdziałanych za pośrednictwem Jadwigi odnajdujemy również wzmianki dotyczące wyposażenia mieszkań oraz szeroko rozumianego życia codziennego. Interesująca jest wiadomość dotyczaca „szlachetnej pani Bogusławy, żony pana Szymona, kasztelana gnieźnieńskiego”, która cierpiała na ból głowy, w wyniku którego nie mogła spać, „chociaż podkładała pod glowę delikatne jaśki i miękkie poduszki" "s. Świadectwem używania na trzynastowiecznym Śląsku „spacerówek" dla dzieci jest, jak sadzę, przekaz dotyczący niewidomej sześcioletniej Elżbiety, wędrującej do Trzebnicy wraz z matka, która „zmęczona podróżą zatrzymała na chwilę wózek, w którym wiozła dziecko, pod drzewem, aby odpoczać i nakarmić córkę" ${ }^{67}$. W opiece nad dzieckiem stosowano również kołyski i powijaki. Informacje o nich zawiera opowieść o znanej nam już małej Pietrusze, która zaopiekować się miała niejaka Bogusława. ,Jakkolwiek owa niewiasta podjęła się opieki, ale źle opiekowała się niemowlęciem, albowiem pozostawiła dziecko w kołysce i poszła do sąsiedniego domu wykonać tam jakąś usługę. Tymczasem do izby wpadł wieprz, przewrócił kołyskę, dziecko upadło na twarz i udusiło się po wieloma powijakami" "68. Elementem życia codziennego były zabawy i zabawki. Opisano zabawę Witosławy, córki rycerza Klemensa, która „odzyskawszy wzrok natychmiast pobiegła zrywać kwiaty na pobliskiej łące" ${ }^{69}$. Bez wątpienia używano do zabawy instrumentów muzycznych, najczęściej wykonywanych samodzielnie przez dzieci, skoro kości piszczelowe Henryka, syna sędziego z Prusic porównano do „zaledwie małej fujarki, na której się gra"70. Pewna dziewczynka, opisana w Żywocie, „bawiła się ze swoja matką wesoło klaszcząc w dłonie. Tym radosnym zachowaniem rozproszyła poprzedni ponury nastrój" ${ }^{71}$.

\section{Tamże, s. 88 .}

62 Tamze, s. 96.

${ }^{63}$ Tamże, s. 88. W polowie XIII w. medyczne wyksztalcenie na poziomie uniwersyteckim można było zdobyć praktycznie jedynie na uniwersytecie w Salamance. Bez przeanalizowania metryki tegoż uniwersytetu trudno jednak dywagować na ten temat.

${ }^{64}$ Tamże, s. 98.

65 Tamże, s. 116.

66 Tamże, s. 88.

67 Tamze, s. 91.

68 Tamże, s. 113. Przerażajace w tej opowieści jest to, że „Matka opłakiwała zmarłą córeczkę, a ból jej powiększał strach, że mąż po powrocie do domu skarci ja za zaniedbanie. Gdy małżonek przybył, również opłakiwał śmierć dziecka, ale cierpial nie tyle z samego zgonu córeczki, ile z powodu grzechu zaniedbania".

69 Tamże, s. 88 .

70 Tamże, s. 95.

7 Tamze, s. 117. 
Miracula potwierdzaja wielokrotnie znaną $\mathrm{z}$ literatury wysoką w średniowieczu śmiertelność dzieci. Jej przyczyny były rozmaite, przeważa jednak zła opieka ${ }^{72}$ i nienajlepszy stan higieny, czy może świadomości konieczności troszczenia się o należyty stan tejże. Trzej synowie Piotra z Sokolnika zmarli w wyniku zjedzenia mięsa pochodzącego z chorej owcy, która, jak ,sądził, została poturbowana przez bydlęta i dlatego straciła siły. Zabił ją więc i wszyscy w rodzinie jedli z niej mięso" "73. Często umierali również rodzice dzieci ${ }^{74}$; w tym przypadku opiekę nad sierotami przejmowal, zgodnie z prawem, najbliższy krewny ze strony ojca - tak stało się w przypadku opisanego w Żywocie Przybka, którym opiekowali się „babka jego i Radzik z Pielaszkowic, krewny ojca" 75 . Z uwagi na relatywnie krótki czas życia posiadamy stosunkowo niewiele informacji na temat rodzin wielopokoleniowych ${ }^{76}$.

Na koniec wypadnie zastanowić się nad oddziaływaniem społecznym Zywota ${ }^{77}$, a co za tym idzie wplywem wzorców wychowawczych zawartych w tekście na kształtowanie się metod wychowania w średniowiecznym spoleczeństwie. Oczywistą kwestią jest, że dzieło historiograficzne powiazane jest z epoka i grupa spoleczna, w której żyje jego twórca. Autor utrwalił bowiem pewne modele funkcjonujące $w$ jego otoczeniu, a zarazem kształtował mentalność swoich odbiorców. Starania o kanonizację Jadwigi rozpoczęła w 1243 r. jej córka ksieni trzebnicka Gertruda. Spośród zakonnic wyznaczono kustoszki, których zadaniem było spisywanie wiadomości o cudach. Pierwszy cud zdziałany za pośrednictwem Jadwigi miał miejsce w 1249 r. Kanonizacja Jadwigi i ogłoszenie jej kultu wywarly znaczacy wpływ na dynastię Piastów, porównywalny z kultem św. Elżbiety ${ }^{78}$. Praktyki ascetyczne, pobożność, uczynki miłosierdzia znalazły szybko naśladowczynie wśród księżnych np. u Anny ${ }^{79}$.

Wśród osób uwiecznionych w Żywocie jest wielu urzędników dworskich, rycerzy, mieszczan. Pielgrzymowali najczęściej do grobu Jadwigi mieszczanie wrocławscy, przedstawiciele stanu rycerskiego, ale też chłopi, młynarze, robotnicy. $Z$ oczywistych względów kult świętej, a co za tym idzie wzorce płynace $z$ jej Żywota, najsilniej wpływały na ludność Ślaska (do Trzebnicy podróżowali - w świetle danych płynących z tekstu - mieszkańcy Wrocławia, Oleśnicy, Brzegu, Opola, Legnicy). Wśród patników odnajdujemy jednak również przybyszów z Wielkopolski (Gniezna, Koźminka), Pomorza a nawet $\mathrm{z}$ Miśni. Treść Żywota świętej Jadwigi była zatem znana zarówno wśród wykształconego kręgu duchowieństwa, dworów książęcych i możnowładztwa, ale również dzięki kaznodziejom trzebnickim wśród rzesz pielgrzymów korzystajacych z posiadanych przez opactwo trzebnickie przywilejów odpustowych ${ }^{80}$. Ponadto w połowie XV w. Żywot św. Jadwigi został przetłumaczony na język niemiecki, a w 1504 r. Konrad Baumgarten wydał go drukiem w nakładzie około 400 - 500 egzemplarzy ${ }^{81}$.

\footnotetext{
${ }^{72}$ Doskonałym przykładem braku opieki nad dzieckiem jest zawarta w Żywocie historia Mikolaja, syna młynarza, który wpadł pod koło mlyńskie, tamże, s. $111-112$.

${ }^{73}$ Tamże, s. 93. Co ciekawe, brak w tekście jakichkolwiek reakcji na śmierć dzieci: ojciec modli się u św. Jadwigi jedynie o powrót do zdrowia.

${ }_{74} \mathrm{~W}$ przypadku kobiet najczęstszą przyczyną zgonów były komplikacje okoloporodowe - „Szczęsława, żona Mateusza z Tyńca, będąc w połogu została porażona paraliżem rąk i nóg, tak że trzeba było ja karmić i poié przez rurke trzcinowa [...] sadzono powszechnie, że ta niewiasta niebawem umrze". Tamże, s. 104. Izentruda, mieszczka wroclawska, będaca w ciąży, ,gdy upłynęlo 9 tygodni, powinna była poczuć ruchy płodu w łonie, a gdy tego nie było, przelękła się, że grozi jej niebezpieczeństwo śmierci", tamże, s. 110.

is Tamże, s. 95.

${ }^{76}$ Np. „Pani Wisława, żona Ulryka, cześnika pana Henryka księcia Śląska, miała wnuka imieniem Nanker”. Tamże, s. 104; ,Idka, córka Łukasza, mieszczanina wrocławskiego" była z wizyta u dziadka w Raciborzu., tamże, s. 108 .

7 Por.: H. Manikowska, Legenda św. Jadwigi - obieg i transformacja, w: Kultura elitarna a kultura masowa w Polsce późnego średniowiecza, red. B. Geremek, Wrocław 1978, s. 160 i nn.

${ }^{78}$ M. Michalski, Kobiety $i$ świętość, s. 189 i nn.

79 Vita Annae ducissae Silesiae dostępny jest od niedawna w tłumaczeniu E. Skibińskiego w: M. Michalski, Kobiety $i$ świetość, Aneks, s. 311 i nn.

${ }_{80}$ Zob.: H. Manikowska, Ruch pielgrzymkowy na Ślasku w późnym średniowieczu - problemy badawcze, w: Peregrinationes. Pielgrzymki w kulturze dawnej Europy. Colloquia Mediaevalia Varsoviensia II, red. H. Manikowska, H. Zaremska, Warszawa 1995 , s. 255 i nn.

81 Tamże, s. 237.
} 